\title{
Why Garden for Wildlife?
}

s a child I was lucky to have Nature as a friend. The long, smooth branch of an old sycamore that grew at the edge of our neighborhood creek was a favorite childhood place to mull things over. Milkweed grew in nearby fields and undeveloped lots, their fascinating seedpods leaking silky threads of dark seeds in the fall that floated off with the wind. Fat toads, butterflies, and fireflies were plentiful, though they were much harder to find when I returned with my daughters many years later. My love for Nature, for plants and wild animals, began in that midwestern town at a time when vacant lots, woods, and uncultivated fields were abundant and children had the freedom and time to explore.

Those memories resurfaced in the spring of 1994, long after I had moved to the San Francisco Bay Area, at a presentation on wildlife habitat gardening at the first Master Gardener conference held at the UC-Davis campus. Two of the presenters were Dr. Don Mahoney, horticulturist at the San Francisco Botanical Garden, and Barbara Deutsch, a wellknown San Francisco butterfly habitat gardener.

Their compelling stories and images of vibrant gardens alive with birds and butterflies were all the inspiration I needed to jumpstart my own journey. It was Don who started me out with checkerbloom (Sidalcea malviflora), my first butterfly host plant, and Barbara, too, shared her wild and wonderful butterfly garden and years of experience. Within several weeks of planting the checkerbloom, tiny caterpillars of the West Coast Lady butterfly appeared. It was a thrilling moment, followed by two quick lessons in butterfly gardening: (1) if the host plant is small, you need more than one, and (2) butterfly caterpillars

OPPOSITE: A pedestal birdbath in the author's garden is a favorite watering hole for birds that forage in a hedgerow of Rosa rugosa, Buddleia salvifolia, and spice bush (Calycanthus occidentalis). PHOTOGRAPH BY NANCY BAUER.

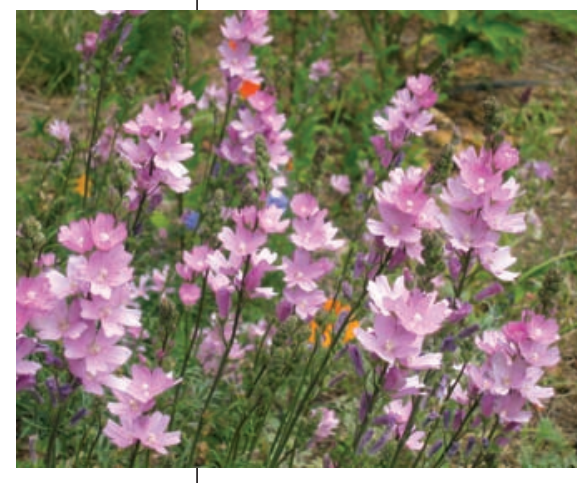

Checkerbloom (Sidalcea malviflora) is a caterpillar food plant for the West Coast Lady butterfly. PHOTOGRAPH BY MIEKO WATKINS. 
have many enemies. I managed to hunt down additional plants, and (with a little additional help) several caterpillars pupated and successfully emerged. It was my first attempt at butterfly habitat gardening and I was completely and unequivocally hooked.

As it turns out there are other reasons to grow wildlife gardens other than for the joy of it. Though the West Coast Lady butterfly can still be found in Bay Area gardens, it is not faring well elsewhere in northern California. "Populations of the once-abundant West Coast Lady," says Arthur Shapiro, University of California-Davis butterfly expert, "are down to about 10 percent of what they were 20 years ago in the southern Sacramento Valley," and the "once common Anise Swallowtail is teetering on the brink of regional extinction." Butterflies that were once routinely showing up in gardens - Acmon Blues, Tailed Blues, Purplish Coppers, and, even, Mourning Cloaks, says

West Coast Lady butterfly. PHOTOGRAPH BY ROBERT WATKINS.
Shapiro, have disappeared not only from urban and suburban neighborhoods, but wild lands, too.

Even the Monarch, our most widely recognized butterfly, has been experiencing severe population declines. The World Wildlife Fund added the Monarch butterfly to its list of "10 to Watch in 2010," along with tigers, polar bears, rhinos, and other threatened species. It's not just butterfly species that are in trouble. Toads, frogs, bees, and some songbird species are disappearing, too, at alarming rates. While experts rarely agree on any one explanation for the decline of wildlife species, the rapid loss and degradation of habitat in California, and throughout the country, is a chief concern. Protected wilderness, which is a very small percentage of our total available land, provides only fragmented and isolated islands of habitat. Unprotected wildlife habitat continues to shrink due to roads, development, agriculture, and urban sprawl. In his book Bringing Nature Home, entomologist Douglas Tallamy gives notice: "It has become increasingly clear that much of our wildlife will not be able to survive unless food, shelter, and nest sites can be found in suburban habitats." And which plants we choose to grow, Tallamy points out, determines the diversity and the numbers of wildlife that a particular garden can sustain.

So, now it's up to us. When we create habitat-places for birds, 
butterflies, bees, and other wild creatures to live, find food, and reproduce - we are helping to restore a small part of what has been lost. These creatures are an integral part of our lives and the health of the plants we grow. They clean up excess seeds and bugs, pollinate our fruits, vegetables, and flowers, prevent disease in the garden, and fascinate us with their relationships to each other and with the plants they depend on for survival.

Each wildlife garden has its own unique cast of characters, each habitat gardener his or her own unique experiences. What is common to us all, however, is the irresistible urge to spend as much time in the garden as we can, walking among the plants, observing what's showing up and enjoying the action. Into my twelfth year in a rural setting in west Sonoma County, the garden has settled and matured, yet constantly changes. I tend an average-sized lot, anchored by a huge black oak, at the western edge of a much larger and diversely planted property that has been stewarded by the owners in an exemplary fashion. Instead of the deer herd I gardened with at my first home in Marin County, a marauding band of gophers comes with this territory. Through many failed plantings I have learned which plants they are likely to avoid and which ones are delectable. I use more gopher wire, do grumble a bit, and then look at the upside: they aerate the soil. Years of gardening with wildlife and with plants I love have changed me into a more patient, less "energetic" gardener. I exert less control, I prune lightly, and try to keep "rearranging" at a minimum.

Though I grow non-native habitat plants, which include edibles (berry bushes, herbs, and a small food garden), the focus is natives. Their beauty, rich fragrances, and textures weave together each section of the garden, making the garden whole. Each year, as more native plants are added, the bird and insect life increases. Native bees and hummingbirds feed on whorls of blue, pink, and white lavender-tinged salvia flowers from early spring into summer. Drifts of these four native species (purple sage, Brandegee sage, black sage, and hummingbird sage) are my reliable, look-good-in-any-season, no-care treasures. Hard-working evening primrose often chooses where it wants to be and I almost always 
go along with the plan. Bumblebees coated with pollen stagger from the sunny flowers from late spring into fall; finches do acrobatics on its stalks, feeding on its abundant seed for months. Birds feast on the fruit of coffeeberry, elderberry, native currants, hawthorne, and crabapple. Behind the veggie garden grows a stand of cow parsnip that blooms in the spring. Their white, flat-topped umbels that are so appealing to the tiniest of pollinators remind me of my favorite trail at the Sonoma coast where they grow in profusion. Hedgerows of trees and shrubs, drifts of perennials, vines, grasses, and wildflowers provide berries, seeds, nectar, and pollen through the year without fertilizers or special care and with very little supplemental water.

For many of us, wildlife habitat gardening is not so much a gardening style as a passion that arises from a love of Nature and Her creatures, beauty, wisdom, and design. Certainly one of the main reasons to garden for wildlife is for the joy of it, for the rewards, for the unexpected pleasures. One of my mine is looking up from the computer to see who's in the large earth-cast birdbath in the back garden. One warm sunny day last November I counted seven species - White-crowned and Goldencrowned Sparrows, a Hermit Thrush, a Spotted Towhee, a California Towhee, Bushtits, and a Song Sparrow — all vying for positions! Whether it's the California Towhee enjoying a long, luxurious bath or the quick communal bathing of Bushtits or the occasion line-up for a spot in the water, birdbath action is one of the most delightful perks of a wildlife garden.

I urge you to spend time in your gardens not only to plant or trim or pull weeds, but also to see the season's changes on each plant, to watch a butterfly sipping nectar or discover its tiny pearl of an egg on the backside of a leaf, to hear the hummingbird and bee working the blossoms, and to consciously inhale the fragrance of a flower. In the chapters that follow, California wildlife habitat gardeners share their gardens, their insights, and their own special pleasures and rewards. There are as many ways to create wildlife gardens as there are gardeners to envision them. Who will come and what will happen is the mystery; only the rewards are guaranteed. 
When California was wild, it was one sweet bee-garden throughout its entire length, north and south, and all the way across from the snowy Sierra to the ocean. . . The Great Central Plain of California, Juring the months of March, April, and May, was one smooth, continuous bed of honey-bloom, so marvelously rich that, in walking from one end of it to the other, a distance of more than 400 miles, your foot would press about a bundred flowers at everystep. Mints, gilias, nemophilas, castilleias, and innumerable compositae were so crowded together that, had ninety-nine per cent of them been taken away, the plain would still have seemed to any but Californians extravagantly flowery.

\section{- John Muir, The Mountains of California}

(1894) (Excerpted from The Bee-Pastures, published by Partners for Sustainable Pollination, 2009) 
